\title{
Study of Ethno-Medicinal plants used by the Mishing People of Dhemaji District of Assam, India
}

\author{
Sharma $\mathrm{UK}^{1 *}$ and Hazarika $\mathrm{D}^{2}$ \\ ${ }^{1}$ Department of Botany, Dhemaji College, India \\ 2Department of Economics, Dhemaji College, India
}

*Corresponding author: Uma Kanta Sharma, Department of Botany, Dhemaji College, Dhemaji 787 057, Assam, India, Tel: 9435188138; Email: usharma2@rediffmail.com

\section{Research Article \\ Volume 2 Issue 4}

Received Date: June 08, 2018

Published Date: June 26, 2018

\section{Abstract}

A survey of Ethno-Medicinal plants used by the Mishing people was conducted from June 15, 2015 to February, 2016 in the Mishing populated areas of Dhemaji district of Assam. The survey aimed at identifying the plants used in the general pharmacopoeia among the Mishing communities also using interviews with house wives and mothers who have a rich knowledge on the plants. A total of 40 medicinal plants were recorded from 50 households. Amoebic dysentery, Abscess, Boils, Cough, Conjunctivitis, Diabetes, Epilepsi, Flatulence, Fracture, Gum bleeding, Galactagogue, Gonorrhoea, Headache, Helminthiasis, High blood pressure, Indigestion, Jaundice, Lower back pain, Malaria, Manstrual disorder, Tooth decay, Tuberculosis, Uterine disorder etc. were the major ailments treated in these households. To compare the usages of the plant species an index of performance (Ip) was calculated for each plant species, from the number of citations of treatment actually recorded from the households against proportion of each plant among the general flora. Some plants are widely used by other communities also in similar ways. The plants with high (Ip) are often confirmed to possess effective medicinal substances in the literature.

Keywords: Ethno-Medicinal Plants; Dhemaji; Mishing; Pharmacopoeia; Performance Index

\section{Introduction}

\section{Background of the Study}

Ethno botany is defined as the study of local people's interaction with the natural environment: how they classify, manage and use plants available around them. Over centuries, indigenous people have developed their own locality specific knowledge on plant use, management and conservation. The complex knowledge, beliefs and practices generally known as indigenous knowledge or traditional knowledge develops and changes with time and space, with change of resources and culture. To view this ethnobotanical studies are useful in documenting, analyzing and disseminating knowledge and interaction between biodiversity and human society, how diversity in nature is used and influenced by human activities. Local communities have 


\section{Journal of Natural \& Ayurvedic Medicine}

indigenous experience in categorizations, where they use their perceptions and experiences to categorize plants. From their experience, a number of categorization and classification criteria were developed which is important in plant diversity conservation and management. India is one of the 12th mega biodiversity countries in the world having two hotspots - the Western Ghats and the Eastern Himalayas, based on species rarity and endemism [1,2]. Arunachal Pradesh $(83,743 \mathrm{sq} \mathrm{km})$ occupies a major portion of the Indian Eastern Himalaya-global biodiversity hotspot and the state alone has recorded 5000 species of angiosperms, of which over 500 species of medicinal plants are reported from the state [3-5].

In Dhemaji, though there has been some organized ethno-medicinal studies, there is limited development of therapeutic products and the indigenous knowledge on usage of medicinal plants as folk remedies are getting lost owing to migration from rural to urban areas, industrialization, rapid loss of natural habitats and changes in life style. In Dhemaji, traditional medicine is faced with a problem of sustainability and continuity mainly due to the loss of taxa of medicinal plants. In view of these, documentation of the traditional uses of medicinal plants is an urgent matter and important to preserve the knowledge. The current loss of medicinal plants in the Dhemaji district is due to natural disaster like flood and erosion and anthropogenic factors linked with the loss of valuable indigenous knowledge associated with the plants. Hence, there exists an accelerated devastation of plant resources with loss of indigenous knowledge. The lack of conservation actions and activities is observed in Dhemaji district, as is the case in many other areas in Assam. Even though Dhemaji is known to have a relatively better plant resource and hence, the associated traditional knowledge resource is expected to be significant. The current plant use trend shows that the environment is facing problems of resource depletion and loss of indigenous knowledge like other areas of the country. Thus, concerted ethno botanical research plays a vital role to draw information on plants associated with indigenous knowledge for conservation and sustainable utilization. In addition, right from its beginning, the documentation of traditional knowledge, especially on the medicinal uses of plants, has provided many important drugs of modern day. Among rural communities in Dhemaji district traditional medication is believed to be an important healthcare system, which mainly involves the use of locally available medicinal plants. Some studies were done on some localities of Assam but no study was done to include medicinal plants and indigenous knowledge of the local communities of Dhemaji district in the medicinal records of Assam. This study is believed to add up to the country database of medicinal plants and in documenting local knowledge of the people. This study has been initiated to conduct ethno botanical study of medicinal plants in Dhemaji district and to compile and document indigenous plant based medical knowledge of the people.

World Health Organization (2003) estimated that 80\% of the world's population depends on traditional medicine for their health needs. In many developed countries, traditional herbal remedies are making a comeback as alternatives to modern medicine. The existence of traditional medicine depends on plant diversity and the related knowledge of their use as herbal medicine. India is one of the twelve mega biodiversity hot spot regions of the world and one fifth of all plants found in India are used for medicinal purpose [6]. Nearly 25,000 effective plant based formulations are used in folk medicine by rural communities in India.

Ethno botanical research on medicinal plants is getting much importance and it is included among the advanced research in India during the recent years. Plants have much relevance on Socio-economic, Socio-religious aspects of human life in India. Central India is covered with tropical forests, which are supposed to be rich in biodiversity. However subtropical hill forests are found in few areas. About 500 species of medicinal plants are found in the north eastern region of India. Some of the economically medicinal plants are on the verge of extinction. The endemic and rare flora also found in this region. Dhemaji district situated in the north east corner of India occupies an area of 3,217 square kilometers. It is one of the remotest district of India, at the eastern-most part of Assam. Situated in the foothills of the lower Himalayas it is relatively a small district. Being in a confluence of rivers with the mighty Brahmaputra River flanking the district and its numerous tributaries running through the district, the region is perennially affected by floods. According to the 2011 census Dhemaji district has a population of 688,077. (Source: Dhemaji District Information and Public Relation Officer, Government of Assam)

\section{Study Area}

Botanically the forest of Dhemaji and Lakhimpur districts can be divided into three divisions viz. Mixed, deciduous and mixed deciduous. The forest in the district is either deciduous or mixed evergreen seen scattered in the foothill areas. The forest resources are timber, 


\section{Journal of Natural \& Ayurvedic Medicine}

bamboo and cane with swamps covered with grass and reeds. There are 9 reserved forests namely Subansiri, Jiadhal, Sissi, Simen, Archiac, Jamjing, Senga, Gali and Pova covering an area of 53, 224.11 hectares which is worked out to be just $16 \%$ of the total area of the district. As the major part of the Study Area Dhemaji is located near the foothills of Arunachal Pradesh, it exhibits difference in temperature, rainfall, fog, wind etc. The climate of the district is Per-humid characterized by high rainfall. The annual rainfall of the district ranges from $2600 \mathrm{~mm}$ to $3200 \mathrm{~mm}$. Rainfall generally begins from April and continues till the end of September. July is the rainiest month. The relative humidity varies from 90 to 73 per cent. The temperature varies between $39.9^{\circ} \mathrm{C}$ in summer and $5.9^{\circ} \mathrm{C}$ in winter. Three highly Mishing populated areas like Jonai, Sissikalghar and Dhemaji were selected for this study.

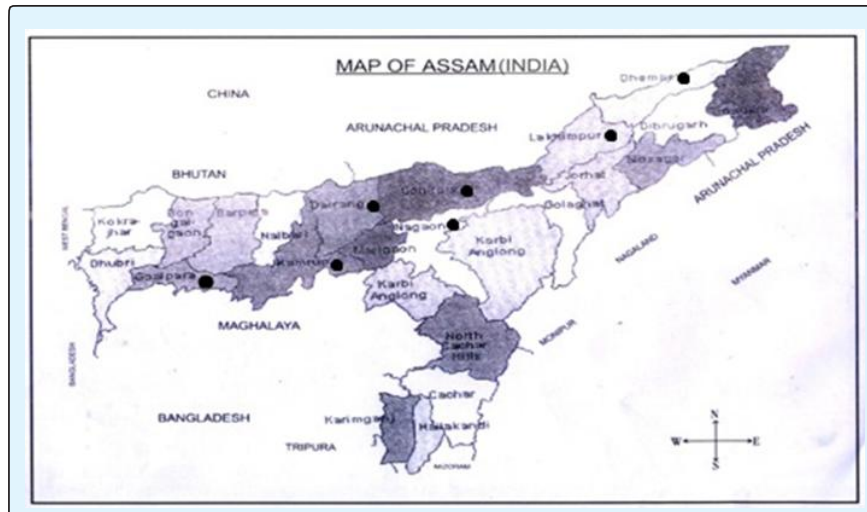

Figure 1: Map of Assam.

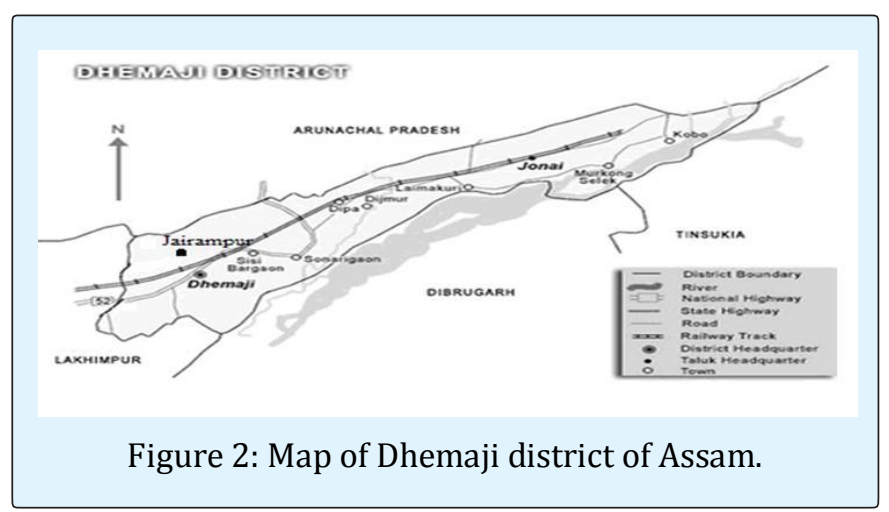

The major ethnic groups of Dhemaji district are Sonowal Kachari, Lalung, Mishing, Bodo, Deuri, Hajong etc. and they live side by side in and outside the reserve forests and in the bank of the river Brahmaputra. These tribes are designated as the Scheduled Tribes (ST) by the constitution of India. These people depend directly or indirectly on the forest resources and agriculture.

\section{About the Mishing Community Undertaken for this Study}

Assam is a land of various tribes and communities located over the entire span of the state. These tribes bear huge cultural and linguistic differences and at the same time similarities too. One of the prominent tribes in the upper Assam is the Mishing tribe. Mishing community an indigenous tribe of Dhemaji district of Assam has been using medicinal plants through many generations of age old, time-tested practices, and as a consequent accumulation of knowledge through a series of observations, interactions and innovations. Mishing (or formerly Miris) tribe comprises of ethnic people inhabiting mainly the Dhemaji, North Lakhimpur, Tinsukhia, Dibrugarh, Sibsagar, Jorhat and Golaghat districts of Assam. Also many of the tribes settled in various districts of Arunachal Pradesh. Although the exact origin of the Mishing people hasn't been confirmed, but it is believed that these people are originally from the hills of Arunachal Pradesh and have lots of cultural and linguistic similarities with the Adi tribe of Arunachal Pradesh. It may be possible that these people migrated towards south in search of a fertile land and settled on the bank of the river. But due to recurring flood of the Brahmaputra River and its tributaries the Mishing people started moving to different safe places of Assam. The Mishing belong to a mixture of East Asian as well as Southeast Asian sub race of the Mongoloid race, similar to the mixture of the Mongoloid sub-races inside political China as people from Southern China may look more like the South East Asian brown-skinned Mongoloids and more towards the Northern China more fair skinned Mongoloids dwell. It's not known exactly where they migrated from, but it is popularly believed that they were dwellers of the hills of present day Arunachal Pradesh. There is no written history of Mishing about their migration from hills to the plains of Assam. Though they belong to Tani group of tribes and they used to be hill dwellers, they started living on the banks of rivers in plains of Assam.

Mishing live in thatched houses raised on bamboo stilts. This is called a 'Chaang ghar' (Figure 3) which means house on stilts. Under the raised structure they keep their domestic animals. This 'Chaang ghar' helps to protect themselves from flood as they basically live in flood prone areas. They basically depend upon agriculture, and that is why they chose to live at the fertile 


\section{Journal of Natural \& Ayurvedic Medicine}

river bank area. The Mishing women are born artists, which reflect in their designs of clothes. They wear clothes that they weave themselves which very beautifully designed. Their food habits are also quite different from other tribes of Assam. The chief festival of Mishing is Ali-Aye-Ligang which they celebrate during the month of February at the beginning of their sowing season. This is actually worship to their god. They follow 'Donyi Polo' as their God and offer lots of food along with living animals to Him. But now days they also follow Hinduism. Some also follow Christianity. Because of the repeated flood they are affected economically. But they still live in the banks of the Brahmaputra River and continue their unique cultural identity.

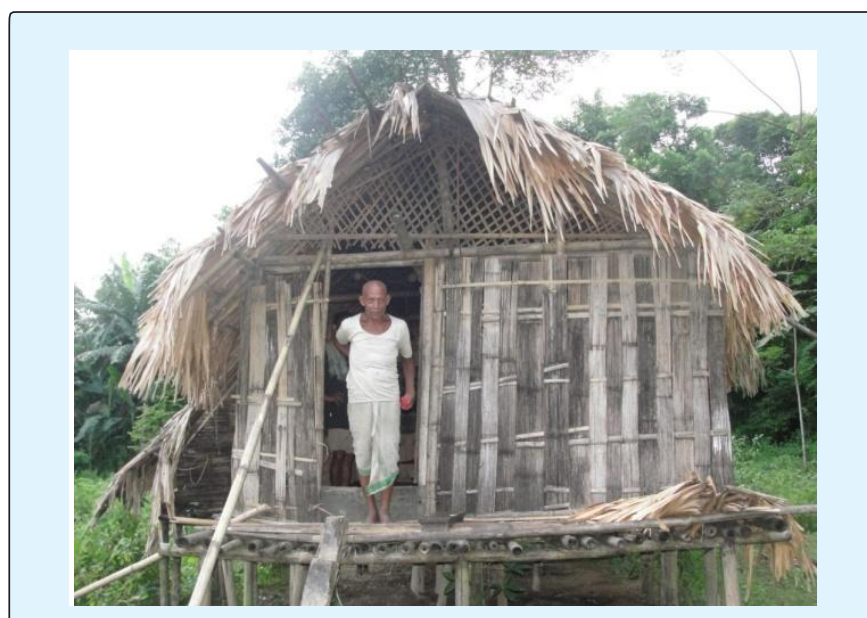

Figure 3: A Mishing medicine man coming out from his house (Chang ghar).

\section{Materials and Methods}

\section{Survey and Selection of Site}

In order to document the knowledge of traditional medicine used by the indigenous Mishing tribes of Dhemaji district of Assam a survey of study area was conducted from June 15, 2015 to February, 2016. Three highly Mishing populated areas like Jonai, Sissikalghar and Dhemaji were selected for the study. A questionnaire was used at the time of interview. The questionnaire included local name of the plant, parts used, mode of use, ailments etc. During the survey two interviewing methods were followed. The first was the 'specimen display' method. Plant species were shown to the traditional healers. The same plant was shown to different healers of the district to confirm the accuracy of the results. The second interviewing method was to walk through the forest with the healers for both plant identification and detailed information gathering.

\section{Sampling Informants}

The informants interviewed numbered 285 (176 men, 109 women) whose ages ranged from 30 to 85 (average age $=57-58$ ) and who mainly belonged to families which had strong links with traditional activities of the area. The informants were purposively selected based on recommendation from elders and local authorities or Village heads (Gams/Gaon buras). They were interviewed in local language. The 153 interviewees were aged over 45; 132 informants were aged under 45, and one interviewee was aged about 85. 20 female informants and 70 male informants studied up to Class VI to Class VIII level and the rest were illiterate. In recording the information of diseases, although enough care was taken to translate this into medical terms, but many information were put 'as it is' at many places to refer exactly whatever was reported, so as to avoid the information being in any way fallacious. All collections were made by the first author who could speak local language and also familiar with some of the traditional plants used by the local tribal people of the region. Herbalists were interviewed using a semi-structured questionnaire. The second author accompanied in field visit and helped in the analysis of the data and photography. A total of 20 field visits (3-4 days in each survey) were conducted during the study period. The questionnaire was mainly focused to collect local names of the plants, plant parts used, method of preparation and associations with other plants, and how such knowledge is preserved and transmitted to next generation. With the help of local informants, the plant material was collected and dried following the standard herbarium procedures [7]. The taxonomic identification of some collected plant specimens was also made with the help of herbarium materials of Botanical Survey of India, Shillong. The voucher specimens were deposited in the Department of Botany, Dhemaji College, Assam for future reference.

\section{Data Analysis}

\section{Informant Consensus Factor (ICF)}

In order to evaluate the reliability of information during the interview, informants were contacted at least two times for the same ideas and the validity of the information was proved and recorded. Consequently, if the idea of the informant deviates from the original information, it was rejected since it is considered as unreliable. Only the relevant ones were statistically 


\section{Journal of Natural \& Ayurvedic Medicine}

analyzed. This method was adopted from Alexiades [8]. The medicinal plant uses were classified into categories following the standard developed by Heinrich, et al. [9]. To test homogeneity of knowledge on the use of plants in the illness categories between the populations, the ICF method was applied. The ICF is calculated for each category to identify the agreements of the informants on the reported cures for the group of ailments. The ICF were calculated as follows:

$$
I C F=\frac{n u c-n s}{n u c-1}
$$

where

nuc $=$ number of use citations in each category

ns $=$ number of species used for each citation

The factor provides a range of 0 to 1 , where a high value acts as a good indicator for a high rate of informant consensus. As for example in case of Malaria disease the ICF is determined as follows. Here nuc $=12$ and $\mathrm{ns}=5$

$$
\begin{aligned}
\text { ICF } & =\frac{n u c-n s}{n u c-1} \\
& =\frac{12-5}{12-1} \\
& =0.64
\end{aligned}
$$

The factor provides a range of 0 to 1 , where a high value acts as a good indicator for a high rate of informant consensus.

\section{Level of Fidelity (FI)}

Moreover, the level of fidelity (Fl) of Friedman, et al. [10] is computed to determine the most preferred species used in treatment of particular ailment as many plant species may be used in the same use category:

$$
\mathrm{Fl}(\%)=\frac{S F}{T F} 100
$$

where

$\mathrm{SF}=$ Frequency of citations of a species for a specific ailments.

$\mathrm{TF}=$ Total number of citations of that species.

As for example, in case of Acacia fermensiana Linn. for treating ailment malaria the $\mathrm{Fl}$ is determined as follows

$$
\begin{gathered}
\mathrm{SF}=3 \\
\mathrm{TF}=10 \\
\text { Therefore } \mathrm{Fl}=\frac{3}{10} \times 100=30 .
\end{gathered}
$$

40 different human ailments were treated by the traditional healers using various medicinal plant species.
The degree of consensus in terms of ICF was observed among the traditional healers in treating the diseases (Table 1).

\section{Performance Index of Medicinal Plants}

Performance Index is proposed by Betti [11,12]. For analyzing the data, "specific flora" is defined as the list of the plants used for treating a specific ailment. The 'global flora' is defined as the total list of plants recorded to be used for all types of ailments. The relationship between the 'specific flora' and 'global flora' can be inferred as follows. If the use of a specific plant for a specific ailment is randomly selected, the proportion of the number of citations to the total number of citations $\left(\mathrm{P}_{1}\right)$ would be similar to the proportion of specific flora to the global flora $\left(\mathrm{P}_{2}\right)$. To illustrate the selectivity of a plant for a specific ailment a comparison is made here between the expected and observed values of the proportion of citation of a plant for a specific disease. The difference (D) between the two proportions is then used to define a Performance Index (IP), which ranges from 0 to 3 according to the following arbitrary scale -

(i) If $\mathrm{P}_{1}-\mathrm{P}_{2}<0$, IP $=0$, the plants concerned are rejected, not significant.

(ii) If $0<\mathrm{P}_{1}-\mathrm{P}_{2}<1 / 3$, IP $=1$, average performance.

(iii) If $1 / 3<\mathrm{P}_{1}-\mathrm{P}_{2}<2 / 3$, IP $=2$, high performance.

(iv) If $\mathrm{P}_{1}-\mathrm{P}_{2}>2 / 3, \mathrm{IP}=3$, very high performance.

To illustrate this, an example is given for the performance index of plant, Acacia fermesiana Linn. used for treating mal., Him, ctv.

\section{Ailments: Malaria}

- Acacia fermesiana Linn

$\mathrm{C}_{1}=$ No of citations of A ...................... for treating Mal.

$=3$

$\mathrm{C}_{2}=$ No of citation of $\mathrm{A}$ inter global list

$=10$

$\mathrm{C}_{3}=$ total no. of citations of the Mal.

$$
=12
$$

$\mathrm{C}_{4}=$ total no. of citations for all ailments $=335$

The proportion of the no. of citations to the total no. of citations

$$
\begin{aligned}
\mathrm{P}_{1} & =\frac{C_{1}}{C_{2}} \\
& =\frac{3}{10} \\
& =0.3
\end{aligned}
$$




\section{Journal of Natural \& Ayurvedic Medicine}

The proportion of specific flora to the global flora,

$$
\begin{aligned}
\mathrm{P}_{2} & =\frac{C_{3}}{C_{4}} \\
& =\frac{12}{335} \\
& =0.04
\end{aligned}
$$

Difference between the two proportions

$$
\begin{gathered}
\mathrm{D}=\mathrm{P}_{1}-\mathrm{P}_{2} \\
=0.26 \\
\therefore 0<\mathrm{P}_{1}-\mathrm{P}_{2} \leq=\frac{1}{3}
\end{gathered}
$$

\begin{tabular}{|c|c|c|c|c|c|}
\hline Ailments & Scientific name of the plant & Pl part & Pharm & Adm & Noc \\
\hline Group: & \multicolumn{5}{|c|}{ Cardiovascular disorder } \\
\hline $\mathrm{Hbp}$ & Clerodendrum colebrookianum Walp. Ln: Pakkom & If & de & or & 5 \\
\hline $\mathrm{Hbp}$ & Rauvolfia serpentina (L.) Benth.ex Kurz. Ln: Sarpagandha & $\mathrm{rt}$ & in & or & 3 \\
\hline $\mathrm{Hbp}$ & Urena lobeta L. Ln: Bor sonborial & lrt & de & or & 3 \\
\hline $\mathrm{Hbp}$ & Elaeocarpus sphaericus (Gaertn)K. Schum Ln: Rudraksha & sd & de & or & 2 \\
\hline $\mathrm{Hbp}$ & Terminalia arjuna Ln: Arjun & bk & de & or & 3 \\
\hline $\mathrm{Hbp}$ & Allium sativum L. Ln: Rasun & $\mathrm{cl}$ & $\mathrm{ch}$ & or & 2 \\
\hline $\mathrm{Ht} \mathrm{Bn}$ & Phyllanthus emblica L Ln: Amloki & $\mathrm{ft}$ & in & or & 1 \\
\hline Ht.Bn & Tinospora cordifoloa Miers Ln:Amorlota & if & de & or & 1 \\
\hline Ht.Bn & Meyna spinosa (Roxb.)ex. Link Ln: Kotkura & $\mathrm{fr}$ & de & or & 1 \\
\hline $\mathrm{Ht} \mathrm{Bn}$ & Elephantopus scaber L. Ln: Bon tamaku & $\mathrm{rt}$ & in & or & 1 \\
\hline Group: & \multicolumn{5}{|c|}{ Digestive system disorder } \\
\hline Amd, & Aegle marmelos (L.) Corr Ln: Bel & $\mathrm{ft}$ & plp & or & 17 \\
\hline Amd & Centella asiatica (L.) Urban Ln: Manimuni & If & in & or & 16 \\
\hline Amd & Mangifera indica L. Ln: Am; Ke:di & bk & de & or & 13 \\
\hline Dir & Clerodendrum indiccum (L.) Kuntze Ln: Akalbih & $\mathrm{ft}$ & plp & or & 10 \\
\hline Dir & Ficus racemosa L. Ln: Tajig & $\mathrm{tl}$ & de & or & 15 \\
\hline Dir & Acacia catechu (L)Willd Ln: Khoir & bk & de & or & 12 \\
\hline Clr & Aloe vera (L.) Burm. Ln: Chalkuwari & If & in & or & 13 \\
\hline Ind & Oldenlandia corymbosa L Ln: Bonjaluk & wp & in & or & 11 \\
\hline Ind. & Carica papaya Linn.. Ln: Ombita & $\mathrm{ft}$ & de & or & 11 \\
\hline Flt & Capsicum frutescence L. Ln: Lukuni murchi & $\mathrm{ft}$ & de & or & 13 \\
\hline Group: & \multicolumn{5}{|l|}{ Dental problem } \\
\hline Tac & Achyranthe aspera L Ln: Hakota bon & st & $\mathrm{ms}$ & $\mathrm{bt}$ & 4 \\
\hline Tac & Calotropis procera Br. Ln: Ako ata esing & $\mathrm{rt}$ & as & la & 3 \\
\hline Tac & Solanum khasianum Clarke Ln: Bangko & sd & $\mathrm{sm}$ & or & 5 \\
\hline Tac & Spilanthes paniculata L. Ln: Morsang & $\mathrm{fl}$ & in & gl & 3 \\
\hline Tac & Zanthoxylam nitidum (Roxb.) DC Ln: Onger & rt.bk & ms & $\mathrm{bt}$ & 5 \\
\hline Gbl & Blumea lacera DC. Ln: Barbie & If & in & la & 4 \\
\hline Gbl & Zanthoxylam nitidum (Roxb.) DC Ln: Onger & rt.bk & de & or & 6 \\
\hline Gbl & Leucas plukenetii (Roth) Spreng Ln: Boga Doron & lf & ju & la & 5 \\
\hline Gbl & Nicotiana tabacum L Ln: Tambaku & If & ju & la & 4 \\
\hline Gbl & Azadirachta indica A.Jussieu Ln: Nim & lf & $\mathrm{Ju}$ & la & 5 \\
\hline Group: & \multicolumn{5}{|l|}{ 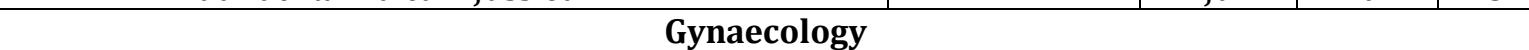 } \\
\hline Glg & Alternanthera sessilis (L.) R.Br.ex DC Ln: Jig jalapa & wp & de & or & 4 \\
\hline Glg & Curculigo orchioides Gaertn Ln: Nagini & $\mathrm{rt}$ & in & or & 4 \\
\hline Glg & Plantago erosa Wallich Ln: Singa & wp & in & or & 4 \\
\hline Glg & Musa paradisiaca L Ln: Kopak & $\mathrm{fl}$ & de & or & 4 \\
\hline
\end{tabular}

Hence performance Index (IP) $=0.26$, average performance.

\section{Results and Discussion}




\section{Journal of Natural \& Ayurvedic Medicine}

\begin{tabular}{|c|c|c|c|c|c|}
\hline Glg & Polygonum chinensis Linn Ln: Bihlongi & If & in & or & 7 \\
\hline Glg & Trachelospermum fragrans Hook.f . Ln: Lota bagini & bk & de & or & 7 \\
\hline Glg & Amaranthus spinosus L. Ln: Hati Khutura & If & de & or & 4 \\
\hline Glg & Euphorbia pulcherrima Willdenow ex Klotzsh Ln: Lalpata & ltx & in & or & 3 \\
\hline Mnd & Spondias pinnata (Linn.f.) Kurz. Ln: Amora & $\mathrm{rt}$ & in & or & 2 \\
\hline Mnd, & Cyperus rotundus L v Ln: Mutha bon & $\mathrm{rt}$ & de & or & 2 \\
\hline Mnd & Butea monosperma (Lam.)Taubst. Ln: Polas & bk & de & or & 3 \\
\hline Mnd & Artemissia indica Willd Ln: Tapin & If & in & or & 2 \\
\hline Group: & \multicolumn{5}{|l|}{ Genital problem } \\
\hline Gnh & Houttuynia cordata Thunb Ln: Mosundori & If & de & or & 2 \\
\hline Gnh & Curculigo orchioides Gaer. Ln: Nagini & $\mathrm{rt}$ & in & or & 1 \\
\hline Urp & Fleurya interrupta Gaudich Ln: Peji & $\mathrm{rt}$ & de & or & 2 \\
\hline Urp & Xanthium strumarium Linn Ln: Tanggom & $\mathrm{rt}$ & de & or & 2 \\
\hline Utd & Polygonum hydropiperL Ln: Pathrua Bilogoni & wp & in & or & 1 \\
\hline Utd & Asparagus racemosus Willd Ln: Hotmul & $\mathrm{rt}$ & in & or & 1 \\
\hline Group: & \multicolumn{5}{|l|}{ Musculo skeletal system } \\
\hline Lbp & Seleginella spp. P.Beauv Ln: Mane okang & wp & in & or & 1 \\
\hline Lps & Calotropis procera Br. Ln: Ako ata esing & Rt.bk & de & la & 1 \\
\hline Frc & Cissus Quadrangular L Ln: Herhurua lata; Along gv:sut & st & in & la & 1 \\
\hline Rat & Alpinia galangal ( L.) Willd Ln: Karphul; Gandhi & $\mathrm{rt}$ & in & la & 2 \\
\hline Rat & Sida rhombifolia L. Ln: Sunalika & st & de & or & 1 \\
\hline Group: & \multicolumn{5}{|l|}{$\begin{array}{l}\text { Parasitic disease } \\
\end{array}$} \\
\hline Mal & Acacia fermesiana Linn. Ln: Kodombor & St.bk & de & or & 8 \\
\hline Mal & Alstonia scholaris (L.) R. Br Ln: Chatiyana & st.bk & de & or & 7 \\
\hline Mal & Gomphostemma parviflora Wall Ln: Bhedaitita & If & de & or & 9 \\
\hline Mal & Solonum torvum Lin. Ln: Sita- bangko & $\mathrm{rt}$ & in & or & 6 \\
\hline Mal & Xanthium strumarium Linn Ln: Tanggom & $\mathrm{rt}$ & de & or & 8 \\
\hline $\mathrm{HIm}$ & Acorus calamus L. Ln: Alokoni; Bosh & $\mathrm{rt}$ & de & or & 7 \\
\hline HIm & Adhatoda vasica Nees Ln: Kampon Baok & lf & in & or & 8 \\
\hline HIm & Carica papaya Linn.. Ln: Ombita & sd & de & or & 6 \\
\hline Hlm & Solonum indicum Lin Ln: Bangko & $\mathrm{ft}$ & in & or & 4 \\
\hline Group: & \multicolumn{5}{|l|}{ Skin disease } \\
\hline Scb & Cassia alata L. Ln: Kharpat & If & in & la & 14 \\
\hline Scb & Gomphostemma parviflora Wall Ln: Bhedaitita & If & pt & la & 12 \\
\hline Rnw & Acorus calamus L Ln: Alokoni, Bosh & $\mathrm{rt}$ & $\mathrm{pt}$ & la & 13 \\
\hline Rnw & Aloe vera (L.) Burm Ln: Chalkuwari & If & $\mathrm{pt}$ & la & 9 \\
\hline Rnw & Gomphostemma parviflora Wall Ln: Bhedaitita & If & $\mathrm{pt}$ & la & 14 \\
\hline Rnw & Mirabilis jalapa Linn Ln: Donyi appun & lf & pt & la & 10 \\
\hline Sir & Aloe vera (L.) Burm Ln: Chalkuwari & If & in & la & 12 \\
\hline Bls & Mirabilis jalapa Linn Ln: Donyi appun & If & $\mathrm{pt}$ & la & 11 \\
\hline Group: & \multicolumn{5}{|l|}{ Respiratory problem } \\
\hline $\mathrm{Cgh}_{,}$ & Achyranthes aspera L. Ln: Hakota bon & wp & de & or & 8 \\
\hline Cgh & Acorus calamus L Ln: Alokoni, Bosh & $\mathrm{rt}$ & de & or & 6 \\
\hline Cgh & Caesalpinia bonduc (L.) Roxb Ln: Letaguti & sd & de & or & 8 \\
\hline Cgh & Clerodendrum indicum (L) Kuntz. Ln:Akalbih & $\mathrm{rt}$ & de & or & 7 \\
\hline Ast & Adhatoda vasica Nees Ln: Kampon Baok & lf & in & or & 8 \\
\hline Brn & Alpinia galanga (L.) Willd Ln: Karphul; Gandhi & $\mathrm{rt}$ & in & la & 7 \\
\hline TB & Asparagus racemosus Willd Ln: Hotmul & $\mathrm{rt}$ & de & or & 6 \\
\hline TB & Sida rhombifolia Linn Ln:Sunalika & st & de & or & 7 \\
\hline
\end{tabular}




\section{Journal of Natural \& Ayurvedic Medicine}

\begin{tabular}{|c|c|c|c|c|c|}
\hline Group: & \multicolumn{5}{|c|}{ Nervous system problem } \\
\hline Hys & Passiflora foetida L. Ln: Nakung & If & de & or & 1 \\
\hline Epl & Rauvolfia serpentina (L.) Benth.ex Kurz. Ln: Sarpagandha & $\mathrm{rt}$ & in & or & 2 \\
\hline Epl & Vitex.nigundo Linn Ln: Posotia & $\mathrm{fl}$ & in & or & 2 \\
\hline Epi & Asparagus racemosus Willd Ln: Hotmul & $\mathrm{rt}$ & in & or & 1 \\
\hline $\mathrm{Hpb}$ & Urena lobata L. & $\mathrm{rt}$ & de & 1 or & 1 \\
\hline Group: & \multicolumn{5}{|l|}{$\begin{array}{l}\text { Specific conditions } \\
\end{array}$} \\
\hline Cwb & Adhatoda vasica Nees Ln: Kampon Baok & If & ju & la & 7 \\
\hline Cwb & Ageratum conyzoides L Ln: Namying eing & lf & in & la & 9 \\
\hline Got & Alpinia allughas (Retz.) Rosc Ln: Talayang akhan, Tora & $\mathrm{rt}$ & in & la & 6 \\
\hline Pls. & Butea monosperma (Lam.) Taub. Ln: Polas & st.bk & de & or & 8 \\
\hline Pls & Desmodium viridiflorum(L.) DC Ln: Bioni sabota & $\mathrm{rt}$ & $\mathrm{pd}$ & la & 9 \\
\hline Jnd & Polygonum glabrum Willd Ln: Bihlongi & $\mathrm{rt}$ & in & or & 8 \\
\hline Dbt & Dillenia indica Lin. Ln: Sompa & $\mathrm{Ft}$ & in & or & 10 \\
\hline Dbt & Scorpia dulcis Linn. Ln: Digie sampek & lf & in & or & 8 \\
\hline Dbt & Tinospora cordifolia (Willd.) Hk.f. \& Thoms Ln: Hagunilota & st & in & or & 10 \\
\hline Hdc & Drymaria cordata Willd Ln: Porrok tapen & wp & $\mathrm{pt}$ & la & 5 \\
\hline Hdc & Passiflora foetida L. Ln: Nakung & lf & de & or & 6 \\
\hline Fvr & Gomphostemma parviflora Wall Ln: Bhedaitita & lf & de & or & 9 \\
\hline Group: & \multicolumn{5}{|l|}{ Animal bite } \\
\hline Snb & Achyranthes aspera L Ln: Hakota bon & $\mathrm{rt}$ & $\mathrm{pt}$ & la & 2 \\
\hline Snb & Rauvolfia serpentina (L.) Benth.ex Kurz. Ln: Sarpagandha & $\mathrm{rt}$ & ju & la & 2 \\
\hline Inb & Alocasia indica (Roxb.) Schott Ln: Ange & lf & ju & la & 1 \\
\hline Inb & Aloe vera (L.) Burm. Ln: Chalkuwari & lf & ju & la & 1 \\
\hline Inb & Nicotiana tabacum L Ln: Tambaku & lf & $\mathrm{ju}$ & la & 1 \\
\hline Inb & Carica papaya Linn Ln: Ombita & lf & ltx & la & 1 \\
\hline Inb & Clerodendrum viscosum Vent Ln:Dhopat tita & lf & $\mathrm{ju}$ & la & 1 \\
\hline $\mathrm{Ob}$ & Murraya koenigii (L.) Sprengel Ln: Narhing & bk & $\mathrm{pt}$ & la & 1 \\
\hline $\mathrm{Ob}$ & Ocimum basilicum L. Ln:Bon tuloki & If & pt & la & 2 \\
\hline $\mathrm{Ob}$ & Urtica dioica L Ln: Sorat & $\mathrm{rt}$ & pt & la & 1 \\
\hline Group: & \multicolumn{5}{|l|}{ Eye problems } \\
\hline Ctv & Acacia fermesiana Linn Ln: Kodombor & lf & de & la & 1 \\
\hline Ctv & Aloe vera (L.) Burm. Ln: Chalkuwari & If & ju & la & 1 \\
\hline Ctv & Butea monosperma (Lam.) Taub. Ln: Polas & $\mathrm{fl}$ & in & la & 2 \\
\hline Ctv & Euphorbia hirta L Ln: Gakhirati bon & lf & ju & la & 1 \\
\hline Ctv & Mangifera indica L. Ln: Am; Ke:di & $\mathrm{bk}$ & de & la & 2 \\
\hline Ctv & Artemisia indica Will. Ln: Tapin & Lf & in & la & 1 \\
\hline Ctv & Clerodendrum viscosum Vent Ln:Dhopat tita & lf & in & la & 1 \\
\hline $\mathrm{Ctv}$ & Oxalis corniculata L. Ln: Tengesi & lf & in & la & 1 \\
\hline Ctv & Tamarindas indica L. Ln: Teteli & If & de & la & 1 \\
\hline
\end{tabular}

Table 1: Citations of Medicinal plants among the Mishing community of Dhemaji district of Assam [Abreviations used : Number of citations $=$ Noc; Local names $=$ Ln $]$.

Ailments: Amoebic dysentery (Amd); Asthma (Ast); Boils (Bls); Bronchites (Brn); Cough (Cgh); Cut wound bleeding (Cwb); Conjunctivitis (Ctv); Cholera (Clr); Diabetes (Dbt); Diarrhoea (Dir); Epilepsi (Epl); Flatulence (Flt); Fracture (Frc); Fever=Fvr; Gum bleeding (Gbl); Galactagogue (Glg ); Gout (Got); Gonorrhoea (Gnh); Hydrophobia (Hpb) Headache Hdc); Hysteria (Hys); Helminthiasis (Hlm);
High blood pressure (Hbp); Heart burn=Ht.bn, Indigestion (Ind); Snake bite (Snb); Insect bite (Inb); Other bite (Obt) ;Jaundice (Jnd); Lower back pain (Lbp); Leprosy (Lps); Malaria (Mal); Manstrual disorder (Mnd); Piles (Pls); Rheumatoid arthritis (Rat); Scabies (Scb); Ring worm (Rnw); Skin irritation (Sir) ; Toothache (Tac); 


\section{Journal of Natural \& Ayurvedic Medicine}

Tuberculosis (TB); Urinary problem (Urp); Uterine disorder (Utd)

Plant part (Pl.part): = stem bark = st.bk Leaf= lf; Root= rt; fruit=ft; Flower=fl; Seed =sd;
Pharmaceutical form (Pharm): = decoction= de; infusion=in; Pulp=Plp; Pound $=$ pd; Masticate $=$ Ma; Juice= ju; Ash=as; Seed smoke=sm; Paste=pt; Masticate $=m s$ ] Mode of Administration (Adm): oral=or, Local application=la, Gargle= gl; Brush teeth= bt]

\begin{tabular}{|c|c|c|c|}
\hline Group of ailments & Ailments & Noc & Total \\
\hline \multirow[t]{2}{*}{ Cardio Vascular Disease } & High blood pressure & 18 & \\
\hline & Heart burn & 4 & 22 \\
\hline \multirow[t]{5}{*}{ Digestive system disorder } & Amoebic dysentery & 46 & \\
\hline & Diarrhoea & 37 & \\
\hline & Flatulence & 13 & \\
\hline & Indigestion & 22 & \\
\hline & Cholera & 13 & 131 \\
\hline \multirow[t]{2}{*}{ Dental problem } & Toothache & 20 & \\
\hline & Gum bleeding & 24 & 44 \\
\hline \multirow[t]{2}{*}{ Gynaecology } & Lactation failure & 37 & \\
\hline & Manstrual disorder & 9 & 46 \\
\hline \multirow[t]{3}{*}{ Genital problem } & Urinary problem & 4 & \\
\hline & Gonorrhoea & 3 & \\
\hline & Uterine disorder & 2 & 9 \\
\hline \multirow[t]{3}{*}{ Musculo skeletal system } & Lower back pain & 2 & \\
\hline & Rheumatoid arthritis & 3 & \\
\hline & Fracture & 1 & 6 \\
\hline \multirow[t]{2}{*}{ Parasitic disease } & Malaria & 38 & \\
\hline & Helminthiasis & 25 & 63 \\
\hline \multirow[t]{4}{*}{ Skin disease } & Scabies & 26 & \\
\hline & Ring worm & 46 & \\
\hline & Skin irritation & 12 & \\
\hline & Boils & 11 & 95 \\
\hline \multirow[t]{4}{*}{ Respiratory problem } & Bronchites & 7 & \\
\hline & Cough & 29 & \\
\hline & Tuberculosis & 13 & \\
\hline & Asthma & 8 & 57 \\
\hline \multirow[t]{3}{*}{ Nervous system problem } & Epilepsi & 5 & \\
\hline & Hysteria & 1 & \\
\hline & Hydrophobia & 1 & 7 \\
\hline \multirow[t]{7}{*}{ Specific condition } & Piles & 17 & \\
\hline & Gout & 6 & \\
\hline & Fever & 9 & \\
\hline & Cut wound bleeding & 16 & \\
\hline & Headache & 11 & \\
\hline & Diabetes & 28 & \\
\hline & Jaundice & 8 & 95 \\
\hline \multirow[t]{2}{*}{ Animal bite } & Snake & 4 & \\
\hline & Insect & 9 & 13 \\
\hline Eye problem & Conjunctivitis & 11 & 11 \\
\hline
\end{tabular}

Table 2: Group of ailments, Ailments and number of citations recorded during interview with the Mishing people of Dhemaji district. 


\section{Journal of Natural \& Ayurvedic Medicine}

40 different diseases under 13 groups of ailments were recorded as human health problem that are treated by 76 plant species (Table 2), one species can treat a single disease or a number of diseases. The practitioners of the area commonly diagnose each health problem by an interview and visual inspection of the patient. These shows large numbers of diseases have got solution by traditional medicine in Dhemaji district. According to the informants the largest number of species was used to treat Gynecological problems and some diseases under Specific conditions which are treated with 12 species each. Digestive system disorder like Amoebic dysentery, Diarrhea, Flatulence, Indigestion, Cholera etc is common disease in the area because most people drink unhygienic water collected from ponds or streams so the people are very much susceptible to different types of water born diseases; the next is skin diseases which are treated by 8 species. Skin diseases like Scabies, Ringworm, Skin irritation, Boils etc are also very common in the study areas due to the unhygienic style of living. Another very common problem found among the Mishing people is Malaria and Helminthiasis. Dhemaji district is a Malaria prone district but the Mishing people seldom use the mosquito nets. Besides they also frequently suffer from Helminthiasis particularly from round and tape worms. This is due to the filthy surroundings caused by the domestic animals like pigs, hens, cows etc. The practitioners were also visited more for diseases like tooth ache, gum pain, lactation failure menstrual disorder, animal bite, urinary problem and others. The local community prefers traditional healers for such diseases rather than modern medication.

\begin{tabular}{|c|c|c|c|}
\hline Group of ailments & Species & Use of citations & ICF \\
\hline Cardio Vascular Disease (CVD) & 10 & 22 & 0.571 \\
\hline Digestive system disorder (DSD) & 10 & 131 & 0.93 \\
\hline Dental problem & 10 & 44 & 0.79 \\
\hline Gynaecology & 12 & 46 & 0.755 \\
\hline Genital problem & 6 & 9 & 0.375 \\
\hline Musculo skeletal system & 5 & 6 & 0.2 \\
\hline Parasitic disease & 9 & 63 & 0.87 \\
\hline Skin disease & 8 & 95 & 0.925 \\
\hline Respiratory problem & 8 & 57 & 0.875 \\
\hline Nervous system & 5 & 7 & 0.333 \\
\hline Specific condition & 12 & 95 & 0.882 \\
\hline Animal bite & 10 & 13 & 0.25 \\
\hline Eye problem, Ear problem, Nose smell, Mouth smell & 9 & 11 & 0.2 \\
\hline
\end{tabular}

Table 3: Informant consensus factor by categories of diseases in the study area [ICF= Informant Consensus Factor].

As the Table 3 shows the Digestive system disorder (DSD) and Skin disease each have scored the highest informant consensus factor of 0.930 and 0.925 followed by Specific condition, Parasitic disease, Dental problem, Gynecology each have scored an informant consensus factor of $0.882,0.870,0.790,0.755$ respectively. A high ICF value (close to 1) indicates that the informants use relatively few taxa to manage specific disease conditions as well as consistency in the use of plant species, while a low value indicates that the informants disagree on the taxa to be used in the treatment within a category of illness. The lower informant consensus factor $(0.200)$ in this study scored for the category of diseases like eye, ear, nose and mouth problems. This category may be indicative for lack of consistency in the use of plant species in the study area.

\section{Threat and Conservation Practices to Medicinal Plants}

In Dhemaji district from the interview of informants, various factors were recorded as the main threats for medicinal plants in the area. There is loss of plants as a result of agricultural encroachment, firewood, charcoal, timber, construction material are contributing factors for the loss of plant species in general and medicinal plants in particular. According to the traditional healers, nowadays searching of medicinal plants require long time and moving long distance even going to neighboring districts of Assam and Arunachal Pradesh to collect the plants. Even some healers have started to grow some medicinal plants in in their home garden as a result of scarcity of plants in the wild. Some of the traditional healers might have given much attention to the indigenous knowledge 


\section{Journal of Natural \& Ayurvedic Medicine}

transfer while others have little concern regarding the value of indigenous knowledge. In general, the knowledge on medicinal plants become lesser and lesser due to its secrecy (unwilling to give this knowledge to others with a belief that if they do so the medicine will not work and their reputation will be bad), unwillingness of young generation to gain the knowledge, oral based knowledge transfer, unavailability of the species, influence of urbanization, modern education and awareness factors which all results in gradual loss of indigenous knowledge on medicinal plants in the area. A remarkable traditional medicinal plant knowledge and practice was documented from the study area. Older traditional healers had greater knowledge and use of ethno-medicinal plant species than younger traditional healers. The average age of the traditional healers was 57.92 years. The fact that $70.83 \%$ of the healers were aged above 50 years implies that the legacy of the use of traditional medicines to manage diseases is in danger of being permanently lost if quick efforts are not exerted to document this invaluable knowledge. As a result, the community suffered an important erosion of ethno-medicinal plant knowledge. It is a fact that as traditional healers who value traditional knowledge are becoming very old, the indigenous medicinal plants use knowledge was declining among the younger generation, which could be attributed to the low interest of the younger generation to inherit and use ethno-medicinal knowledge.

Ethno-medicinal knowledge diminishes with the death of elderly knowledgeable persons. A key informant from one of the study areas with an age of 70 said "I wanted to tell my knowledge of medicinal plants to my sons but they are not interested now I fear this knowledge will be permanently lost at the time when I die." This saying indicates that there is poor ways of transferring knowledge on medicinal plants. Depending on the age of the healers passing the knowledge of numerous species of ethno-medicinal plants use, management and ways of preparation are threatened. Results also revealed that many of the traditional healers reported to transfer their knowledge and use of ethno-medicinal plants orally to their favorite family member. Such transfer of indigenous knowledge is liable to erosion as it could vanish when knowledgeable elders die before the knowledge is transferred. The practitioners know the importance of conserving medicinal plants; home gardens are good places for conservation of medicinal plants and for better transfer of the indigenous knowledge to the younger generation. Some traditional practitioners have started to conserve medicinal plants by cultivating at home gardens. This paves a way for knowledge on medicinal plants to pass from generation to generation. Moreover, some plant species like Rauvolfia serpentine, Elaeocarpus sphaericus, Meyna spinosa, Clerodendrum indicum, Zanthoxylam nitidum, Butea monosperma, Artemissiaindica, Asparagus racemosus, Cissus quadriangularis, Gomphostemma parviflora, Adhatoda vasica, Caesalpinia bonduc, Vitex nigundo, Alpinia allughas, Urtica dioica were found in threatened state in Dhemaji district. There might be some endemic plant species in the study areas which needs a detailed botanical study throughout the area.

\section{Conclusion}

Dhemaji district is relatively rich in medicinal plant diversity. Seventy six medicinal plants were recorded to treat human ailments. The medicinal plant species collected and identified were from both wild vegetation and home gardens. In the study area, 40 ailments were reported which are being treated by 76 traditional medicinal plants of the area. 27 herbs were found the dominant habits used for preparation of traditional remedies followed by 24 trees 22 shrubs and 3 climbers. Leaves were also found to be the most frequently used plant parts followed by roots for preparation of human remedies. Traditional medicine preparation mostly involves single plant; the mode of administration is mainly internal in which oral administration is the common route. The main threat for medicinal plants in the area arises from agricultural expansion, firewood, charcoal production, timber production and construction. Threat comes to medicinal plants due to lack of their sustainable utilization. Whereas threats that erode indigenous knowledge emanate from secrecy, oral based knowledge transfer, reluctance of young generation to gain the knowledge, unavailability of the species, influence of modern education and awareness factors are the major ones. Therefore, awareness rising should be made among the healers so as to avoid erosion of the indigenous knowledge and to ensure its sustainable use.

\section{References}

1. Agarwal KC (1999) Biodiversity. Agrobotanical publishers, Bikaner, India.

2. Myers N, Muttermeier RA, Muttermeier CA, da Fonseca GAB, Kent J (2000) Biodiversity hotspots for conservation priorities. Nature 403: 853-858.

3. Baalu TR (1999) Anonymous Forest Survey of India. State of Forest Report 1999, Ministry of Environment and Forests, Government of India, Dehra Dun. 


\section{Journal of Natural \& Ayurvedic Medicine}

4. Murtem G (2000) Common wild vegetables of Nyishi tribe of Arunachal Pradesh. Arunachal For News 18: 66-77.

5. Haridasan K, Anupam Sharma (2003) Medicinal plants sector in Arunachal Pradesh an overview, Indian Forester, Dehradun, pp: 37-47.

6. Schippmann U, Leaman JD, Cunningham AB (2002) Impact of cultivation and gathering of medicinal plants on biodiversity: Global trends and issues, Inter-Departmental Working Group on Biological Diversity for Food and Agriculture, Rome.

7. Jain SK, RR Rao (1977) Hand Book of Field and Herbarium Methods. (Today and Tomorrow Printers and Publishers), BSI, Calcutta.

8. Alexiades M (1996) Selected guidelines for ethnobotanical research: A field manual. New Botanical Garden, New York.
9. Heinrich M, Ankli A, Frei B, Weimann C, Sticher O (1998) Medicinal plants in Mexico: Healers' consencus and cultural importance. Social Sci Med 47(11): 1859-1871.

10. Friedman J, Yaniv Z, Dafni A, Palewitch D (1986) A preliminary classification of the healing potential of medicinal plants, based on a rational analysis of an ethnopharmacological field survey among Bedouins in the Negev Desert, Israel. J Ethnopharmacol 16(23): $275-287$.

11. Betti JL (2002a) Usages populaires des plantes galactogènes dans l'arrondissement de Mintom au sud de la Réserve de biosphère du Dja (Cameroun). Soma 2: 35-46.

12. Jain SK (1987) A manual of Ethnobotany. Scientific publishers, Jodhpur, India.

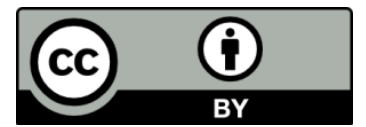

